\title{
The Role of Parliament in Consolidating Democracy Under the Federal Democratic Republic of Ethiopia (FDRE) Constitution
}

\author{
Solomon Tefera* \\ Ambo University, Ambo, Ethiopia
}

\begin{abstract}
Institutional Parliamentary System has been in practice in Ethiopia since the time of imperial Haile Selassie, but it was not powerful until the end of EPRDF. Empirical evidences reveal that Ethiopian parliament system did not adequately consolidate democracy to discharge constitutionally bestowed duties and responsibilities. The aim of this paper, therefore, was to examine the role of parliament in consolidating democracy under the FDRE Constitution. The study employed qualitative research method. To organize the qualitative data, secondary sources such as journal articles, legal documents, governmental, books, non-governmental reports, and media outlets were used. A descriptive data analysis technique was used for data analysis. Accordingly, the study indicated that the Ethiopian parliament highly dominated by executive organ, the safeguard of executive power and its interest rather than the guard of FDRE constitution. The study gave further insight that Ethiopian parliament under the EPRDF government has been formulating various proclamations that violate the basic democratic and human rights of the Ethiopian people. Media, political parties, anti-terrorist, and Civil Society Organization laws were cases in point; among the bottlenecks to exercise democratic and human rights. As a result, the Ethiopian parliament has failed to check whether the executive is acting with the framework of the laws. The study suggests that having autonomous institutions such as independent judiciary system, election board, human rights commission, and ombudsman as well as empowering the parliament is vital for democracy to flourish.
\end{abstract}

Keywords: Democracy, Constitution, Parliament

DOI: $10.7176 /$ RHSS/11-9-04

Publication date:May $31^{\text {st }} 2021$

\section{Introduction}

In a democratic system, institutions can play a key role in consolidating the democratic system. In a democratic system, these institutions should be independently run their responsibilities. However, in some countries, these institutions are strongly fused. For instance, in most African countries including Ethiopia, there are no independent democratic institutions as there is a tendency of interference by one institution in the affairs of the other. In Ethiopia, for more than four decades democratic institutions had been dominated by the king (Haile Selassie 1931-1974), and under the military government, it was dominated by what? Since 1991 all democratic institutions were subdued to and served the will of the executive.

The imperial regime adopted the first written constitution in the 1931, later revised in 1955, with Emperor Haile Selassie (1930-1974), and during the imperial regime, the emperor was the sole remaining sovereign body (Fiseha, 2015). While the bulk of the provisions of both constitutions reiterated about an uncontested power of the Emperor, both constitutions provided for a bicameral House: the Chamber of Deputies and the Senate (Fiseha, 2015). These two houses were important instruments for curbing the power of the king. But what happened, in reality was that the role of the parliament was reduced to providing an advisory role to the king. According to Article 31 of the 1931 constitution, members of the Senate were appointed by the emperor from among the nobility and the local chiefs. As for the chamber of Deputies, they were chosen by the nobility and the local chiefs. The presence of the nobility while providing some semblance of legitimacy at the center became part of a toothless legislative body and in a way remained the instrument of the centralizing and modernizing process launched by the regime.

The Revised Constitution of 1955 continued to reinforce further the powers of the Emperor. The sketchy provisions regarding the powers and prerogatives of the Emperor were extensively elaborated in the new Constitution. In theory, the Constitution was the supreme law of the land governing even the Emperor ${ }^{1}$. It contemplated even an independent ministerial government responsible to the monarch and parliament, an elected chamber, and an independent judiciary but these liberal provisions were overshadowed by executive prerogatives reserved to the Emperor who exercised them expansively (Fiseha, 2015). Despite the apparent inclusion of the notion of separation of powers, little change was introduced regarding the position of the Emperor. He was both the head of state and of the government and he continued to oversee the judiciary through his Zufan Chilot (Crown Court). A basic change made in development in the revised constitution compared to its predecessor was the introduction of the representative principle for the chamber of Deputies whose members were elected based

\footnotetext{
${ }^{1}$ Legislative - Executive Relations in the Ethiopian Parliamentary System: Towards Institutional and Legal Reform
} 
on universal adult suffrage. But parliament was granted no control over the ministers, who remained responsible to the Emperor. Under Imperial regime the parliament had no any power to decide on political and economic issues, all power letdown in the hand of king (Teshome, 2009).

The military government took political power in 1974 by over through Imperial Haile Selassie. Then, after 17 years the Military governments adopted a new constitution and declare a new parliament called National Shengo or General Assembly. The 1987 constitution give a lot of power to the national Shengo. The powers of National Shengo were amending the constitution; determining foreign, defense, and security policy; establishing the boundaries, status, and accountability of administrative regions; and approving economic plans. The National Shengo was also responsible for establishing the Council of State; the Council of Ministers, ministries, state committees, commissions, and state authorities; the Supreme Court; the Office of the Prosecutor General; the National Workers' Control Committee; and the Office of the Auditor-General. Besides, the National Shengo elected the president and officials of the Council of State and approved the appointment of other high-ranking authorities. However, in practice, these powers are handed in the hand of the president (Teshome, 2009).

Following the downfall of the military government in 1991, the Ethiopian political landscape changed from unitary to the federal system with the establishment of a parliamentary democracy system (Merera, 2003). The newly inaugurated parliamentary democracy provided for the establishment of various democratic institutions including the parliament, though their performances have been proved ineffective and weak (Lyons, 2010).

Like other democratic constitutions, the 1995 constitution also included the principle of the separation of power (Amhed, 2011). Under this principle, each government organ has its legal authority that is enshrined in the constitution. In Ethiopian context, the separation of power explicitly put in the FDRE constitution But as has been observed for some quiet time, these

organ are said to have failed practically deliver on their constitutionally guaranteed powers according to FDRE Constitution article 55(16): It shall, on its initiative, request a joint session of the House of the Federation and the House of Peoples' Representatives to take appropriate measures when State authorities are unable to arrest violations of human rights within their Jurisdiction.

The members of the Executive organs include the prime minister appointed by the parliament, and if they fail to undertake their job effectively as per the constitution, then the parliament can also remove them from their post. However, the Ethiopian parliament has never been lived up to its constitutional responsibilities under the EPRDF (Ahmed, 2011). Hence, this paper attempts to examine the role of parliament in consolidating democracy under the FDRE constitution by taking into consideration how they practiced their constitutional enshrined powers. Accordingly, the paper intended to answer two basic research questions. The first question, what are the roles of parliament to consolidate democracy in Ethiopia? And second what are the challenges facing the Ethiopian parliament to use their legal responsibility?

To achieve the above objectives of the research, I employed a case study research design and qualitative research methodology. The case study is a structure of research which focuses on investigating groups, event, institution, or culture (Deribsa, 2017). Stake (1995) argued that case studies, in which the researcher explores in depth a program, events, and activities a process, one or more individuals. Hence, the case study research design is an appropriate paper design that helps to investigate the role of parliament under the FDRE constitution.

Basically, " qualitative research is interpretive in the sense that it attempts to interpret phenomena in terms of the meanings people attribute and draws conclusion through interpreting the data gathered from various sources" (Kothari, 2004:178). Another reason is that it doesn't focus on numerical information (Creswell, 1998). Hence, an approach of writing in which analysis and reflection are interwoven was applied (Bridges, 2002). The paper, as such, is founded on a study of secondary data. The secondary data sources employed for this study includes relevant books, bilateral and multilateral agreements, party documents, official reports, journals, articles, official websites, and a variety of publications and magazines that report about the topic and these sources of data were selected based on their reliability and suitability to the study undertaken.

\section{Legal perspectives consideration}

Ethiopian parliament has two Houses. These are the House of Federation and the House of People Representatives (HPR $)^{1}$. Hence, this paper only examines the House of People's Representative. This paper attempted to examine the role of parliament in consolidating democracy under the FDRE constitution based on the legal perspective. Particularly, it does analysis based on the FDRE constitution article (54) (4) which converse how the parliament should operate. According to this article, the House of People Representative (HOPR) is governed by the constitution, the will of the people, and their conscience. Article 54(1) state that the members of the House of Peoples' Representatives shall be elected by the People for a term of five years based on universal suffrage and by direct, free, and fair elections held by secret ballot (FDRE Constitution, 1995) ${ }^{2}$. The

\footnotetext{
1 See FDRE constitution article 53

${ }^{2}$ See FDRE Constitution article 54(1)
} 
FDRE constitution article 55(16) entrusted the parliament with the power-to protect the democratic and human rights of their people, give the directive to executive organs (FDRE Constitution, 1995) ${ }^{1}$. Hence, this paper analyzes the objectives of the research from the perspective of the above article contained in the FDRE constitution.

\section{Meaning of democracy}

There are different discourses about the meaning of democracy and the essential criteria to consider one system as a democratic system or not. Bereket (1999) argued that democracy can be measured procedurally, and the essence of democracy cannot be the classical approach defined the meaning of democracy depending on the source and purpose of democracy. The source of democracy is people and the ultimate purpose allowed to selfrule. In a democratic government system, the people elect their representatives by a fair and free election. According to the work of the Tilly(2005) in the democratic system the democratic institution independently function their responsibility without any pressure of other body. Similarly, democratic institutions are directly responsible for represented people and their conscience. From the key democratic institution, the parliament has a vital role in building a democratic system. Democracy cannot exist without parliament (Adejumobi, 2009). Democracy, in its various manifestations over the centuries, is by far the most coveted political system that serves to link government to the people. A democratically elected parliament is the only true voice of the people and accountability to the people it serves is the basic plank of a democratic system and one of its core principles is the principle of political equality, meaning that political power should be distributed as widely and evenly as possible among the people. This principle is captured by the adage government of the people, by the people, and for the (ibid).

\section{Parliament and democracy}

The parliament is a key democratic institution that plays a vital role in consolidating democracy. That is why the constitution of a different country gives high authority to the parliament. In Ethiopia, the parliaments have the highest authority at the federal level (FDRE, 1995). The FDRE constitutions give three authorities for the Ethiopian Parliament. Accordingly, the Ethiopian parliament must exercise oversight over executive, legislation, and representation.

In the parliamentary democratic system, the parliaments reflect the will of the people and are governed by the will of the people. Theoretically, the FDRE constitution article 54(1) states that the House of People Representative is governed by the will of the people (FDRE, 1995). Anthony and Alan (2009) on their works argue in theory the parliament is one of the key institution of democracy playing a crucial role in terms of legislation, oversight and representation.

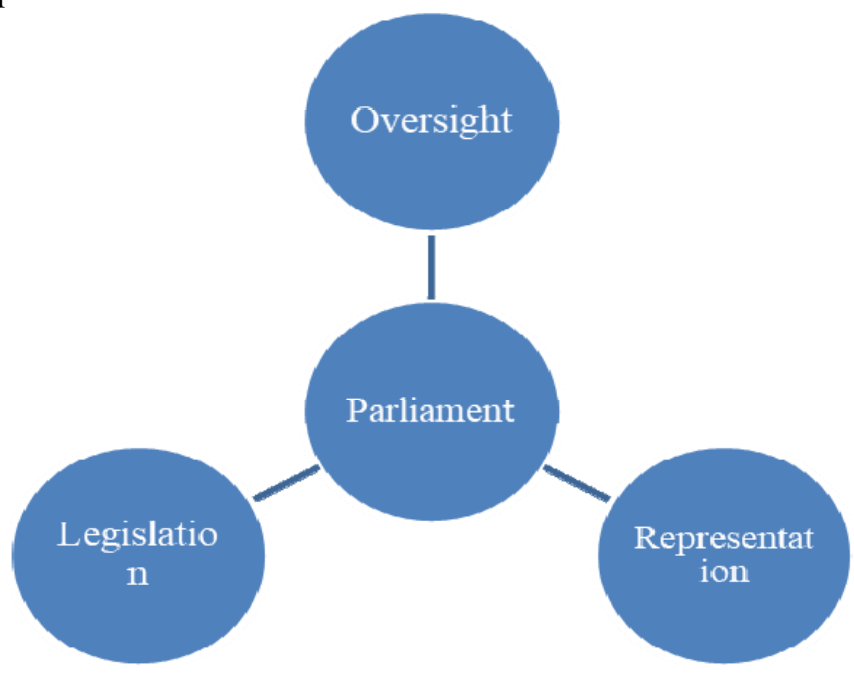

\section{Source: Self-developed}

Based on the above assertions, democracy is the rule of the people and the people governs themselves through their representatives. Hence, the parliament is expected to investigate the interest of the people before passing any policy as the policy affects citizens.

\section{Ethiopian parliament and democracy}

In Ethiopia, the FDRE Constitution gives authority to formulate legislation to the parliament. In the FDRE

\footnotetext{
${ }^{1}$ See FDRE Constitution article 54(16)
} 
constitution article (55) (1) the House of People Representative has the power to make policy or law, and other subsidiary proclamation at the federal level. However, to the contrary, the Ethiopian Parliament-had been enacted different proclamations that violate the democratic and human rights of the Ethiopian People ${ }^{1}$. These prominent proclamations include: are anti-terrorism (2009), Media (2008), political parties (2008), and the Civil Society Organization (2009he anti-terrorism proclamation of Ethiopia a far-reaching effects on the human and democratic right such as freedom of expression and demonstration (Henok, 2013). The Human Right Watch also appeal Ethiopian government in contrary to the FDRE Constitution and International law passed antiterrorism law to limit independent media, International and law journalist. Similarly, the aims of anti-terrorism law serve to close the political space of the country after the 1997 National election (HRW, 2013; Henok, 2012).

The PM Abiy Amhed recognized the Ethiopian government has been violating human and democratic right for more than 20 years ago as well as he has recognized the government action as terrorism ${ }^{2}$.

The anti-terrorism law helps to intimidate, and prison opposition political parties as well as exclude opposition political parties from political participation ${ }^{3}$. Based on this the prominent opposition political parties specifically the Oromo Liberation Front (OLF), the Ginbot-7, and the Ogedan National Liberation Front (ONLF) were listed under terrorist groups. Lastly, with the coming to power of the new Prime Minister Abiy Ahmed, the former anti-terrorism proclamation has been partially repealed and replaced by the newly amended anti-terrorism law which was adopted on January.2, 2019. Until the current transition government of Ethiopia, the minister of council, including the then PM, did not claim about the downside of the anti-terrorism, civil society organization, political parties and media laws.

The FDRE constitution article 55(16) state that article 55(16) have authority to protect the democratic and human right of their people, give the directive to executive organs (FDRE Constitution, 1995).

The parliament must be accountable to the FDRE constitution to passed the law and evaluate the importance of the law that is going to declare. However, the legal and administration affairs standing committee have been the members of the EPRDF and dominated by the executive organs. Hence, the Ethiopian parliament has been the safeguard of executive power rather than the guard of the constitution and their own citizens' rights (Kahsay, 2013). Even though, all drafted proclamations and policy decision on the party level before, submitted to parliament. Then, the executive organ imposed the parliament to implement what they are discussed at the party level. The FDRE constitution Article 77 stipulates the Powers and Functions of the Council of Ministers. Thus, the Council of Ministers ensures the implementation of laws and decisions adopted by the House of People's Representatives (Sub article1), shall formulate and implement economic, social and development policies and strategies (Sub article 6), shall ensure the observance of law and order (Sub article 9) shall submit draft laws to the House of Peoples' Representatives on any matter falling within its competence including draft laws on a declaration of war (Sub artice11). However, contrary to FDRE constitution, the executive organ ensures the implementation of programs adopted by the EPRDF.

According to Anthony and Alan (2009), in the parliamentary democracy the essential role of the parliament is keeping an eye on the activities of the executive and holding the executive account on the behalf of the country's citizens. The FDRE constitution gave this right to the House of People Representative ${ }^{4}$. Based on this right the House of People Representative question's the prime minister or executive organs about human and democratic rights but the Ethiopian parliament did nothing until Prime Minister Abiy came to power.

In the parliamentary democracy as a key democratic institution, the role of parliament is representation. Anthony and Alan(2009) stipulate that representation is about collecting, aggregating, and expressing the concerns, opinions, and preferences of the country's citizens, through the political process. This is achieved when the free and fair election is held.

The FDRE constitution article 54(1) state that the members of the House of Peoples' Representatives shall be elected by the People for a term of five years based on universal suffrage and by direct, free, and fair elections held by secret ballot (FDRE Constitution, 1995).

Since 1991 the EPRDF or (Prosperity Party) has been won five general national successive elections. The only occasion on which something of a threat to the EPRDF dominance emerged was in the 2005 elections when the CUD won 109 seats and UEDF also won 51 seats in the parliament (Solomon, 2018). The five general National elections were not free and fair election (Merera, 2008; Wondwesen, 2009). In general, the Ethiopian parliament has been weak and in effective until the end of EPRDF.

The weakness and ineffective Ethiopian parliament linked with the nature of the Ethiopian Revolutionary Democratic Front (EPRDF). According to Lyon (2010) the nature of political parties are shaped by their origin. He also argued that there is low probabilities the guerilla fighter establish democratic government post military

\footnotetext{
12012 Report of the Un Special Reporters on the Human Rights defenders to the General Assembly; including the criminal legislation, to regulate the activities and work of Human Rights defenders.

2 .The speech of Prime Minister Abiy Amhed on parliament, June 18, 2018

3 The report of Amnesty International ,2013

${ }^{4}$ See FDRE Constitution article, 55(16)
} 
victory, because the ruled by the principle of" We rule because we sacrificed". The United Kingdom philosopher Immanuel Kant argued that changing dictatorial government by non-violent struggle is replacing new dictatorial government with cosmetics politics (1991). Mahatma Gandhi also stipulated that non-violent struggle is more powerful than violent struggle, because there is high probability to establish democratic government. On the other hand, the political parties that originated from guerilla fighter until consolidate their own political power ratified new constitution and establish democratic institution such as independent Judiciary, Parliament, National electoral Board, Human right commission, ombudsman and independent National Defence Force(Lyons,2010). However, all of the above democratic institution they run the interest of ruling party rather than protect constitution.

The EPRDF established democratic institutions for two vital reasons. The first one is, internally to get political legitimacy and consolidate political power until strength themselves interims of military and the second is to cope up the pressure of international community (Western Nation). The American Ambassador Herman J.Cohen (1991) said that if there is no democracy, no cooperation. According to him the American government to cooperative with Ethiopian government interims of economy, political and social activities, the Ethiopian government shall be democratic unless otherwise the there is no cooperation. Following the statement of Ambassador Herman J. Cohen the EPRDF promised to establish democratic government (Henze, 1991) and with having hidden agenda the established democratic institution.

The hidden goal of the insurgent groups is establish strong authoritarian parties. Under this circumstance, it is impossible to think about democratic election because of the nature of political parties determine the quality of democracy (Anthony and Alan, 2009). In addition to this the party members leaders appointed based on their loyalty rather than education background.

The Former Ethiopian Prime Minister said that the Ethiopian People Revolutionary democratic Front (EPRDF) have leader based on the loyalty. We don't have given high attention about his/her education background; we have to focus on his/her loyalty to our party (Interview with ETV in 1998).

In the process of establishing strong authoritarian party there is patronage and client informal political network and the member of network has recruiting based on the party loyalty and commitment for party (Randall and Svåsand, 2001). Since 1991, in Ethiopia the client and patronage network had been applied in the name of 1 to 5 cells (Merera, 2009). The Ethiopian parliament members had been recruiting based on party loyalty and this is affecting the capacity of parliament members.

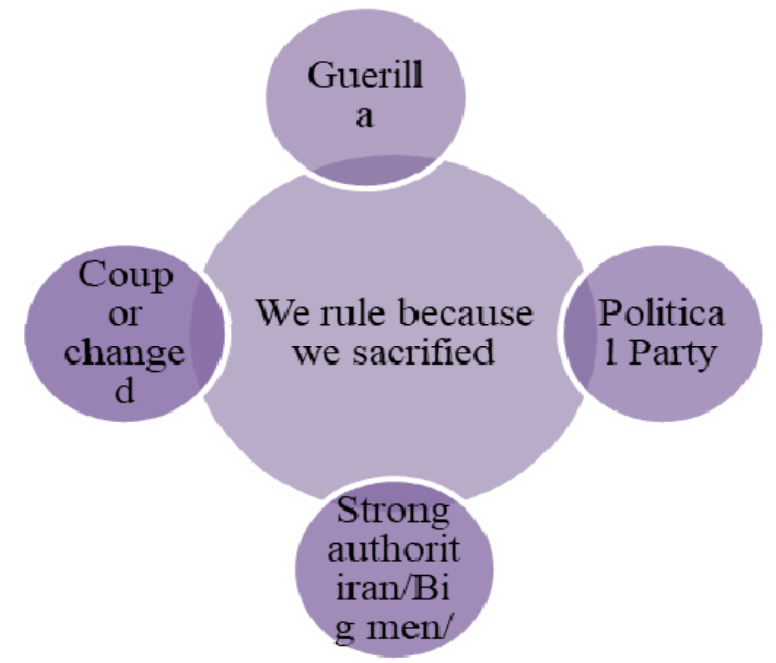

\section{Source: Self-developed}

The ultimate goal of the insurgent group-is to establish strong authoritarian party or rule of big man. For instance, from African countries like Burundi, Rwanda and Uganda are still ruled by Big Men or strong authoritarian party after military victory (Joseph, 2016). In the same way, the Ethiopian People Revolutionary Democratic Front (EPRDF) ruled the country as dominant party-and it put all democratic institutions under its complete tutelage including the parliament (Lyons, 2010; Gudina; 2003; Teshome, 2009).

\section{Conclusion and Recommendations}

The aim of this paper was to examine the parliament role in consolidating democracy under the FDRE constitution. The role of parliament as a key democratic institution is very much dependant on the nature of the party system. The party system is determined by the origin of the party. If the party originated from guerrilla fighter, there is low probability to establish multi-party democratic system with democratic government. The ultimate goal of such kind of party is to establish strong authoritarian party system like the Ethiopian People 
Revolutionary Democratic Front (EPRDF) party. The Ethiopian parliament had been overlooked their constitutional duties and responsibilities that given by FDRE constitution like overseeing, representation and Legislation. Furthermore, along with FDRE constitution the parliament member are expected to be governed by the will of the people, constitution and their consciences. Conversely, the Ethiopian parliament member had been governed by the EPRDF party discipline rather than governed by the constitution, the will of the people and their Conscious.

In the home of the EPRDF, the parliament had been served as instrument to establish the strong authoritarian party system. Hence, the parliament could not have play crucial role in consolidating democratic system rather than guard of the executive power. The Ethiopian Parliament failed to fulfill its constitutional obligations-in this case, it was controlled by the executive. The Ethiopian Parliament had performed poorly because; it was pressurized to endorse the policies proposed by the executive branch. The most important indicators of such laws passed by the parliament after being forwarded include anti-terrorism, media, political parties and civil society proclamations. This implies that, the Ethiopian parliament has a vital role in consolidating strong authoritarian regime rather than consolidating democratic system in Ethiopia.

The finding of this study concluded the setback of the Ethiopian parliament originated from the nature of the EPRDF party. Based on the finding of this study, the researcher put forward the following recommendation. The ruling party and opposition parties should recruit the candidates to the parliament based on the educational background, establish think thank advisor groups to consult and empower the parliament members, establish strong and independent democratic institution such as National Electrol Board (NEBE), Independent Judiciary, Human right commission and ombudsman as well as independent military defense that are accountable to the constitution.

\section{Reference}

Adejumobi, S. (2009). Regional initiatives on governance in Africa: ECA, AU, and ECOWAS interventions. The African Union and new strategies of Development in Africa.

Awel, A. (2011). Parliamentary oversight and its role in ensuring constitutionalism and accountability under the FDRE Constitution (Doctoral dissertation, Addis Ababa University).

Cohen, Herman J. "Africa and democracy." pt2 Department of State Dispatch 2 (1991): 871.

Creswell, J. A. (1998). Five qualitative traditions of inquiry. Qualitative inquiry and research design. Choosing among five traditions, 47-72.

Fiseha, A. (2015). Legislative-Executive Relations in the Ethiopian Parliamentary System: Towards Institutional and Legal Reform. Community Law Centre, University of the Western Cape Constitution-Building in Africa, 239-270.

Gudina, M. (2003). The elite and the quest for peace, democracy, and development in Ethiopia: lessons to be learnt. Northeast African Studies, 10(2), 141-164.

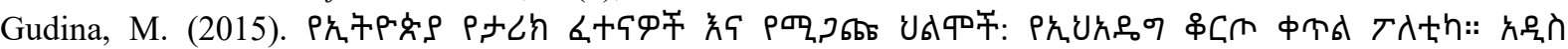

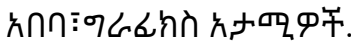

Kahsay, M. 2013. The Legislative Process in Ethiopia: Challenges and prospects (Doctoral dissertation, Addis Ababa University).

Kothari, C. R. (2004). Research methodology: Methods and techniques. New Age International.

Tefera S. (2018): Party politics in Ethiopia: Coalition and fragmentation among opposition political parties since 2005

Lyon, T. P., \& Yin, H. (2010). Why do states adopt renewable portfolio standards?: An empirical investigation. The Energy Journal, 31(3).

Randall, V., \& Svåsand, L. (2001, April). Political Parties and democratic consolidation in Africa, XXIX Joint Sessions of Workshops, ECPR. In Workshop: Parties, Party Systems and Democratic Consolidation in the Third World (Vol. 6, No. 11).

\section{Reference}

Sassoon, J. (2016). Anatomy of authoritarianism in the Arab republics. Cambridge University Press. Refer to Joseph, 2016)

Selassie, B. H. (1998). Democracy and the Role of Parliament under the Eritrean Constitution. NCJ Int'l L. \& Com. Reg., 24, 227.

Stake, R. E. (2005). Qualitative case studies.

Teshome, W. (2009). Opposition parties and the politics of opposition in Africa: A critical analysis. International Journal of Humanities and Social Sciences, 3(1), 1-15.

Tilly, C. (2005). Coalitions across borders: Transnational protest and the neoliberal order. Rowman \& Littlefield.

Tsekpo, A. \& Hudson, A. (2009): Parliamentary Strengthening and the Paris Principles: Uganda case study. 